\title{
The trophic evolution of Lake Iseo as related to its holomixis
}

\author{
Letizia GARIBALDI, Valeria MEZZANOTTE, Maria Cristina BRIZZIO ${ }^{1)}$, Michela ROGORA ${ }^{1)}$ \\ and Rosario MOSELLO ${ }^{1}$ * \\ Dipartimento Scienze dell'Ambiente e Territorio Università degli Studi di Milano, Via Emanueli 15, 20126 Milano, Italy \\ ${ }^{1)}$ C.N.R. Istituto Italiano di Idrobiologia, Largo Tonolli 50, 28922 Verbania Pallanza, Italy \\ *e-mail correspondig author: r.mosello@iii.to.cnr.it
}

\begin{abstract}
Lake Iseo is undergoing a progressive deterioration in water quality, mainly due to eutrophication. This paper, based on measurements performed on the main tributaries and the outflow, considers the phosphorus, nitrogen and silica budget of the lake, related to its trophic evolution. The chief conclusion of the study is that the significant reduction in P load over the last few years following the construction of treatment plants is not enough to reverse the trend to eutrophication and the progressive deterioration in water quality. An attempt to use the OECD statistical approach to quantify the relationships between $P$ load and the trophic condition of the lake yielded poor results, because the characteristics of the lake did not fulfil the hypothesis of the model. The reduced tendency to a complete overturn of the water is one of the most important aspects, leading to hypolimnion anoxia and P release from the sediments.
\end{abstract}

Key words: Iseo, water chemistry, trophic level, nutrient budget

\section{INTRODUCTION}

Lake Iseo, also known as Sebino, lies in the foothills of the Alps, and is fed by the streams of the Val Camonica. It has a maximum depth of $251 \mathrm{~m}$ and lies at an altitude of $185 \mathrm{~m}$ a.s.l., so that the bottom is $66 \mathrm{~m}$ below sea level. At the centre of the lake is the island of Monte Isola which is the largest and highest island in the southern Alpine lakes: it is $4.3 \mathrm{~km}^{2}$ with a maximum height of $599 \mathrm{~m}$ a.s.l., which corresponds to $414 \mathrm{~m}$ above the surface of the water.

The two mountain chains that run parallel to the lake from north to south have a mean elevation between $1000 \mathrm{~m}$ and $1400 \mathrm{~m}$; the mean altitude of the watershed is $1429 \mathrm{~m}$, with a highest point of $3554 \mathrm{~m}$ (Mount Adamello). The main characteristics of Lake Iseo and its watershed are reported in table 1 and figure 1.

The landscape of the western shore is rugged and vegetation is scarce, except for the stretch between Sarnico and Predore where the steep shore is broken and descends gradually into the lake. There are also many other small breaks in the steep, high shoreline, with mountain streams forming little gorges. The eastern shoreline is radically different, being formed mainly of gentle slopes, with abundant vegetation including agricultural crops.

According to its climatic area, Lake Iseo should be classified as warm monomictic. However, as for the other deep southern Alpine lakes, the complete overturn takes place only at irregular time intervals, when the winter is particularly cold and windy (Ambrosetti \& Barbanti 1992; Ambrosetti et al. 1983a; Barbanti \& Ambrosetti 1985, 1989). For this reason, the actual water renewal time, estimated on the basis of a mean outflow of $57.4 \mathrm{~m}^{3} \mathrm{~s}^{-1}$. (Consorzio dell'Oglio 1952, 1984, 1986, 1993), in about 4.2 years. Climate changes in the last decade have led to warmer winter temperatures, stressing the already uneven trend of lake overturn.

Tab. 1. Main characteristics of Lake Iseo and its watershed.

\begin{tabular}{lc}
\hline Lake area & $61 \mathrm{~km}^{2}$ \\
Lake volume & $7.6 \mathrm{~km}^{3}$ \\
Lake height (a.s.l.) & $185 \mathrm{~m}$ \\
Development of the right bank of the lake & $28.56 \mathrm{~km}$ \\
Development of the left bank of the lake & $31.77 \mathrm{~km}$ \\
Island surface & $4.28 \mathrm{~km}^{2}$ \\
Maximum depth & $251 \mathrm{~m}$ \\
Mean depth & $123 \mathrm{~m}$ \\
Theoretical water renewal time & 4.2 years \\
Watershed area (lake included) & $1842 \mathrm{~km}$ \\
Highest altitude (M. Adamello) & $3554 \mathrm{~m}$ \\
Mean altitude & $1429 \mathrm{~m}$ \\
Surface of glacial areas & $19.5 \mathrm{~km}^{2}$ \\
Percent of glacial areas & $1.1 \%$ \\
\hline
\end{tabular}

The watershed includes 83 municipalities, 21 of which are on the shoreline, belonging to the provinces of Bergamo, Brescia and Sondrio, with a total population of about 180,000 inhabitants. The whole of the shoreline area is due to undergo sewage treatment, by two treatment plants located at the northern and southern ends of the lake. The southern system will ultimately collect sewage from about 90,000 equivalent inhabitants and treat it in a plant located at Paratico (Fig. 1). According to the project, waste water is to be diverted from the lake and discharged, after biological treatment, into the outflowing River Oglio. The second treatment plant, located at Costa Volpino, close to the River Oglio inlet (Fig. 1), will receive sewage from 


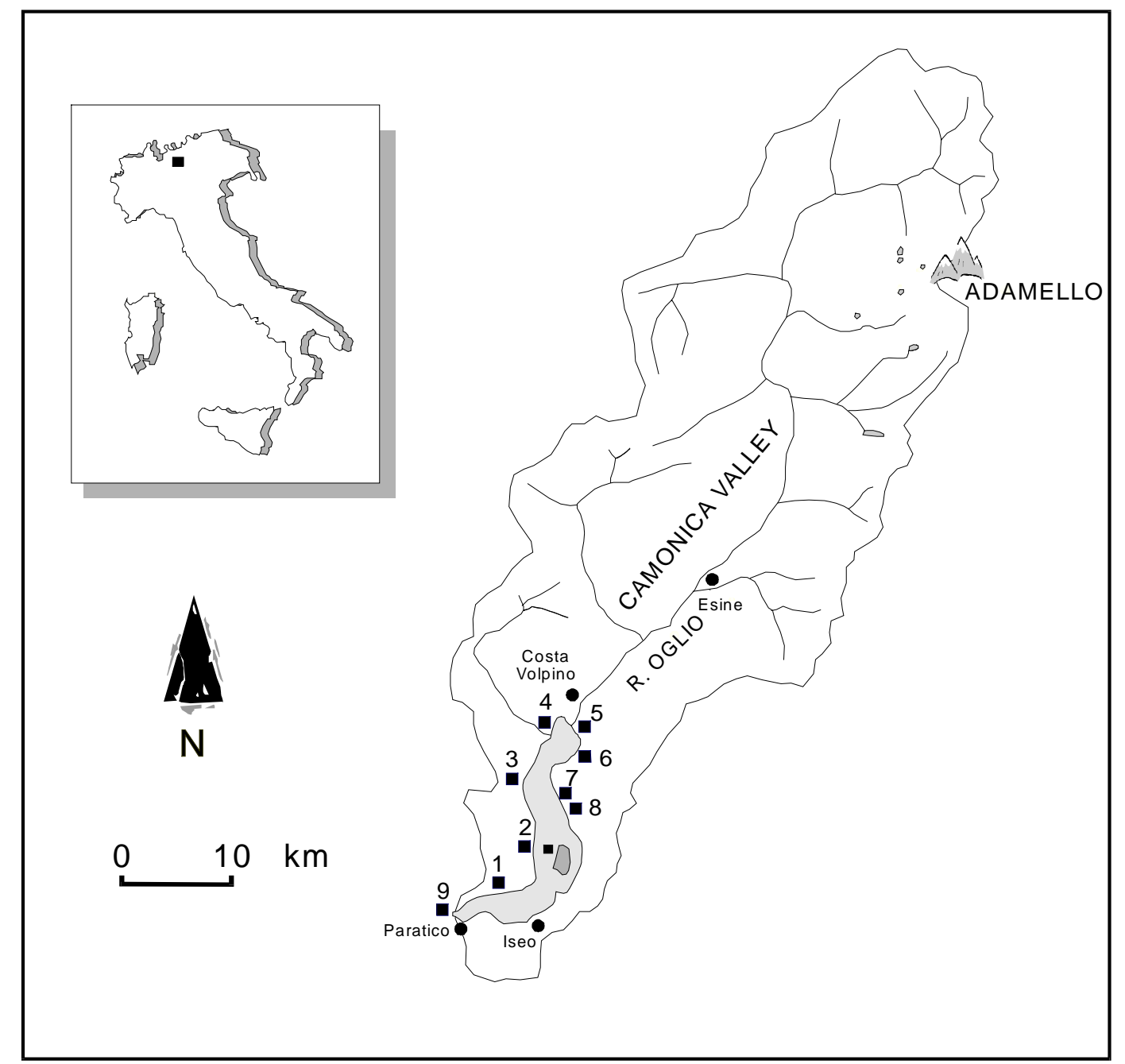

Fig. 1. Lake Iseo and its watershed. Lake sampling station ( $\mathbf{\square})$, sampled tributaries. 1. R. Rino di Predore; 2. R. Acquaiolo; 3. R. Zu; 4. R. Borlezza; 5. R. Oglio Immissario; 6. R. Trobiolo; 7. R. Bagnadore; 8. R. Opolo; 9. R. Oglio Emissario.

80,000 equivalent inhabitants and, besides the conventional primary and secondary treatment, will perform simultaneous phosphorus removal and denitrification. The plant will be fed by a couple of shoreline collectors and by the collecting system of Val Camonica, receiving sewage from all the municipalities along the inflowing River Oglio, downstream of Esine. Data on population, land use, activities, waste water collection, treatment and disposal have been considered in a previous work (Garibaldi et al. 1998).

The first limnological study of Lake Iseo was made in 1967 (Bonomi \& Gerletti 1967); since then several papers have documented a progressive deterioration of the water due to eutrophication (Bonomi 1968; Cordella 1973; Cordella \& Paganelli-Cappelletti 1975; Cordella et al. 1976, 1977, 1979, 1980, 1982; Paganelli et al. 1975, 1976, 1979; Trevisan et al. 1979; Bonomi et al. 1979; Mosello 1983; Ambrosetti et al. 1983b, 1992). Since 1973 annual samplings for chemical analysis have been performed by the C.N.R. Istituto Italiano Idro- biologia, with the aim of describing the trophic evolution of the lake and recording the occurrence of full circulations. However, a thorough study of phytoplankton and chemistry which documents the seasonal variations has not been made since 1972 (Trevisan et al. 1979). The importance of the lake and the evidence of its increasing eutrophication prompted a more detailed study on its chemistry and phytoplankton aimed at specifying the current trophic conditions of the lake (Garibaldi et al. 1995).

The present paper, based on a two year sampling period, aims at estimating the nutrient loads, with special attention to phosphorus, as related to the present trophic situation of the lake and its recent evolution. The experimental $\mathrm{P}$ loads will be compared with those calculated from the population in a previous paper (Garibaldi et al. 1998), with the aim of evaluating the contribution from shore areas and from the part of the watershed not drained by the sampled tributaries. 


\section{MATERIALS AND METHODS}

\subsection{Rivers}

To quantify the nutrient loads entering Lake Iseo, from June 1995 to May 1997 the main tributaries and the outlet (River Oglio) were sampled fortnightly and analysed for $\mathrm{pH}$, total phosphorus, total nitrogen, ammonia, nitrates, silica, alkalinity and conductivity. Ten tributaries and the outlet, draining altogether $91 \%$ of the watershed, were considered during the first year of the study (June 1995 - May 1996). In the second year, both a consideration of the analytical results and the extent of the watersheds concerned led to sampling and analyses being carried out from June 1996 to May 1997 with the same frequency but only on the main inflow rivers (rivers Oglio and Borlezza), draining $88 \%$ of the watershed, and on the lake outlet. The Italsider Canal, an offtake of the River Oglio inflow which receives discharge from several factories located on the northern shore of the lake, was also sampled.

The water chemistry of the tributaries and the outlet are described in greater detail in a separate paper (Garibaldi et al. 1998); the present paper considers only the concentrations and loads of total phosphorus, total nitrogen and reactive silica.

\subsection{Lake}

Following a research programme which has been in progress since 1993, samples of the lake waters were collected monthly in the area of maximum depth at 0,1 , $3,5,10,20,30,5075,100,150,200$, and $245 \mathrm{~m}$. Temperature was measured with a reverse thermometer during the samplings. The results are expressed as epilimnion (0-15 m), hypolimnion (20-258 m) and bottom (200-258 m) concentrations, calculated as volume weighted averages. For more detailed information on the sampling, see Garibaldi et al. (1995, 1997). These temperature and chemical results are considered together with the historical trends, obtained from regular samplings performed since the seventies. See Ambrosetti et al. (1983b) and Mosello \& Giussani (1997) for details of these samplings.

\subsection{Chemical analyses}

Total phosphorus (TP) and total nitrogen (TN) were analysed, after mineralization of the samples, according to Valderrama (1981); reactive silica (RSi) was analysed with molybdate (A.P.H.A., A.W.W.A., W.P.C.F. 1985). Dissolved oxygen, measured in the lake water, was routinely measured with an Oxymeter WTW OXI 196 Microprocessor for every meter along the water column. The results were periodically confirmed by the Winkler method (A.P.H.A., A.W.W.A., W.P.C.F. 1985), especially when there was anoxia or very low concentrations.
On the basis of the average concentration for each tributary, the mean concentrations for the total inflowing water were calculated as weighted values on the watershed area of each tributary.

\subsection{Estimate of chemical loads}

The estimates of loads from the tributaries were made by multiplying the weighted average concentrations of TP, TN and RSi by the total inflow to the lake as measured by the Consortium responsible for the hydraulic regulation of the lake (Consorzio dell'Oglio 1993). The outflowing loads were calculated by multiplying the average concentrations of total phosphorus, total nitrogen and silicates by the total outflow for the considered periods (Consorzio dell'Oglio 1993, 1997, personal communication).

The loads in the part of the watershed not drained by the sampled tributaries $(8.8 \%$ and $11.8 \%$ in the first and second year of study, respectively) were calculated with different methods according to the type of nutrient. In the case of nitrogen and silica, load factors were calculated from the ratio between the area drained by the sampled tributaries and total watershed area. This takes into account the prevailing role of non-point sources of load for these elements (mainly atmospheric deposition for nitrogen, watershed weathering for silica). The atmospheric input to the lake surface was considered significant, compared to the input from the watershed, only in the case of nitrogen. Loads were estimated from deposition values measured in the area during a five year study which involved the whole of Italy (Mosello \& Marchetto 1995). They were 60 and $70 \mathrm{t} \mathrm{N} \mathrm{y}^{-1}$ for 1995-96 and 1996-97, respectively. The relative importance of nitrate and ammonium is about 60 and 40\%, which is the ratio generally found in deposition in the Po Valley (Mosello 1993). In the case of phosphorus, deriving mainly from point sources, the loads were calculated taking into account the population of the areas not drained by the sampled tributaries, using pro-capita coefficients obtained as described in Garibaldi et al. 1998.

\section{RESULTS}

\subsection{Hydrology}

The two considered years were quite different as regards hydrology if compared to the long-term trend (1951-1996) (Fig. 2). The outflow was lower (45 and $\left.54.6 \mathrm{~m}^{3} \mathrm{~s}^{-1}\right)$ than in the reference period (1951-96 average value of $57.5 \mathrm{~m}^{3} \mathrm{~s}^{-1}$ ). The monthly values during the study period are close to the long term means, with the exception of the peak recorded in November 1996 (100 $\mathrm{m}^{3} \mathrm{~s}^{-1} v s$ a mean value of $\left.54.8 \mathrm{~m}^{3} \mathrm{~s}^{-1}\right)$. The inflow to the lake, calculated by the Consorzio dell'Oglio (1997, personal communication), was 44.9 and $55.5 \mathrm{~m}^{3} \mathrm{~s}^{-1}$ in the two years respectively. 
Tab. 2. Watershed area of the sampled tributaries, mean value and standard deviation in the tributaries and in the outflow of Lake Iseo.

\begin{tabular}{|c|c|c|c|c|c|c|c|}
\hline & \multirow[t]{2}{*}{$\begin{array}{l}\text { Watershed area } \\
\left(\mathrm{km}^{2}\right)\end{array}$} & \multicolumn{2}{|c|}{$\begin{array}{c}\mathrm{TN} \\
\left(\mathrm{mg} \mathrm{N} \mathrm{1}^{-1}\right)\end{array}$} & \multicolumn{2}{|c|}{$\begin{array}{c}\mathrm{TP} \\
\left(\mu \mathrm{g} \mathrm{P}^{-1}\right)\end{array}$} & \multicolumn{2}{|c|}{$\begin{array}{l}\text { Reactive silica } \\
\qquad\left(\mathrm{mg} \mathrm{Si}^{-1}\right)\end{array}$} \\
\hline & & mean & s.d. & mean & s.d. & mean & s.d. \\
\hline \multicolumn{8}{|l|}{ Period June 1995 May 1996} \\
\hline Oglio inflow & 1433.86 & 1.65 & 0.23 & 39 & 14 & 2.7 & 0.25 \\
\hline Borlezza & 136.04 & 2.05 & 0.68 & 88 & 70 & 2.3 & 0.22 \\
\hline Canale Italsider & & 1.39 & 0.39 & 50 & 35 & 2.8 & 0.40 \\
\hline $\mathrm{Zu}$ & 11.44 & 3.07 & 0.76 & 62 & 21 & 2.4 & 0.43 \\
\hline Acquaiolo & 4.08 & 2.74 & 0.68 & 78 & 27 & 2.7 & 0.55 \\
\hline Predore & 4.33 & 3.17 & 1.5 & 71 & 215 & 3.3 & 1.41 \\
\hline Opolo & 6.51 & 3.31 & 1.39 & 183 & 139 & 3 & 0.54 \\
\hline Bagnadore & 18.35 & 2.54 & 1.36 & 124 & 125 & 2.2 & 0.27 \\
\hline Trobiolo & 10.43 & 1.66 & 0.45 & 142 & 236 & 3.6 & 1.84 \\
\hline Sampled area & 1625.04 & & & & & & \\
\hline Weighted mean concentration & & 1.72 & - & 46 & - & 2.7 & - \\
\hline Oglio outflow & 1842 & 1.02 & 0.27 & 16 & 8 & 0.5 & 0.13 \\
\hline \multicolumn{8}{|l|}{ Period June 1996 May 1997} \\
\hline Oglio inflow & 1433.86 & 1.66 & 0.23 & 36 & 12 & 2.7 & 0.31 \\
\hline Borlezza & 136.04 & 2.34 & 1.32 & 123 & 177 & 2.5 & 0.58 \\
\hline Canale Italsider & & 1.22 & 0.16 & 29 & 8 & 2.7 & 0.51 \\
\hline Sampled area & 1569.9 & & & & & & \\
\hline Weighted mean concentration & & 1.72 & & 44 & & 2.7 & \\
\hline Oglio outflow & 1842 & 1.01 & 0.23 & 14 & 7 & 0.5 & 0.23 \\
\hline
\end{tabular}

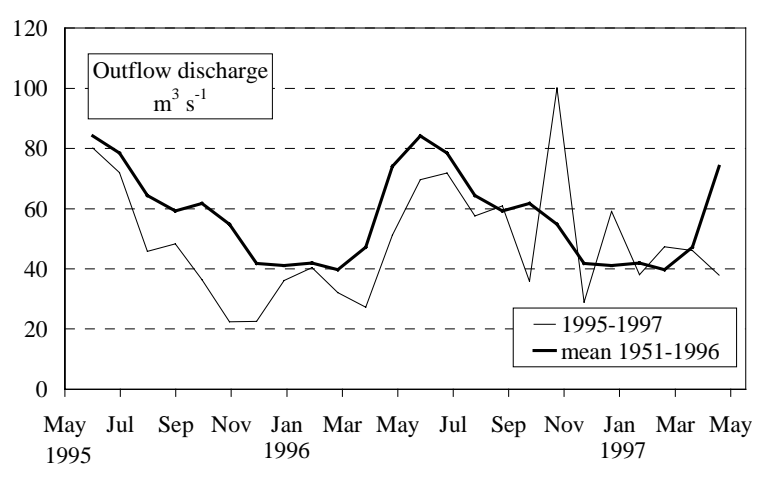

Fig. 2. Monthly values of water outflow in the two study periods compared with the monthly means for 1951-1996.

\subsection{River chemistry}

Table 2 reports the concentrations of TN, TP and RSi in the sampled tributaries for the two periods of the study. Mean concentrations of the total inflowing water are also reported.

In the period June 1995-May 1996 the annual means of the tributaries ranged between 1.39 and $3.31 \mathrm{mg} \mathrm{N}^{-1}$

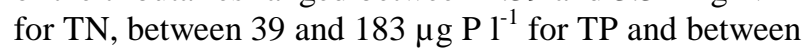
2.2 and $3.6 \mathrm{mg} \mathrm{l}^{-1}$ for $\mathrm{RSi}$. TP concentrations are high in most of the tributaries, with mean values over $70 \mu \mathrm{g} P$ $1^{-1}$, with the exception of three cases (River Oglio inflow, the Italsider Canal and the $\mathrm{Zu}$ Stream). The River Oglio, the main inflow, draining $88 \%$ of the watershed, shows quite low mean values of TP $\left(39 \mu \mathrm{g} \mathrm{P} \mathrm{l}^{-1}\right)$ and TN (1.65 $\mathrm{mg} \mathrm{N}^{-1}$ ). The River Borlezza, the second tributary in importance ( $8.4 \%$ of the watershed), shows much higher TP concentrations ( $88 \mu \mathrm{g} \mathrm{P}^{-1}$ annual average), and $\mathrm{TN}$ values $\left(2.05 \mathrm{mg} \mathrm{N}^{-1}\right)$ only slightly higher than in the River Oglio. The Borlezza contribution strongly affects the weighted means, which were $1.72 \mathrm{mg} \mathrm{N} \mathrm{1}^{-1}$, $46 \mu \mathrm{g} \mathrm{P} \mathrm{l}^{-1}$ and $2.7 \mathrm{mg} \mathrm{Si}^{-1}$ for TN, TP and RSi for the first year of study. In the period from June 1996 to May 1997 only the three main tributaries $(96.4 \%$ of the watershed) were sampled; the annual means were almost exactly the same as those of the previous year (Tab. 2). Concentrations in the outflowing river Oglio were very close in the two periods, both for ranges and for annual means of nitrogen and phosphorus, and exactly the same for silica. Average values for 1995-96 and for 1996-97 were 1.02 and $1.01 \mathrm{mg} \mathrm{N}^{-1}$ for TN, 16 and $14 \mu \mathrm{g} \mathrm{P} \mathrm{l}^{-1}$ for TP and $0.5 \mathrm{mg} \mathrm{Si}^{-1}$ for RSi.

For the lake tributaries the area weighted means for the three variables were $1.72 \mathrm{mg} \mathrm{N} \mathrm{l}^{-1}, 46 \mu \mathrm{g} \mathrm{P} \mathrm{l}^{-1}$ and $2.7 \mathrm{mg} \mathrm{Si}^{-1}$ for the first period and $1.72 \mathrm{mg} \mathrm{N}^{-1}, 44 \mu \mathrm{g}$ $\mathrm{P}^{-1}$ and $2.7 \mathrm{mg} \mathrm{Si}^{-1}$ for the second. In both years the concentrations measured in the Italisider Canal were close to those measured in the inflowing River Oglio, from which its water comes.

The differences in RSi concentrations among the tributaries are lower, indicating the prevalence of weathering processes over point pollution sources.

\subsection{Lake}

The chemistry of Lake Iseo is strongly influenced by the overturn. The oligomictic character of the lake, i.e. water mixing and chemical homogenisation not reaching the deepest waters every year (Ambrosetti \& Bar- 
banti 1992), has changed in recent years to a condition closer to meromixis. This is well illustrated by the temperature and oxygen evolution (Fig. 3): since 1986 the temperature values have regularly increased in the water layers below 200 and $50 \mathrm{~m}$, while oxygen has been regularly decreasing since $1984-86$, so that the water below $200 \mathrm{~m}$ reached reducing conditions in 1995 . Below $50 \mathrm{~m}$ the oxygen saturation is about $20 \%$. The low oxygenation produced a reduction of total nitrogen concentration (Fig. 4a), which decreased from about $1 \mathrm{mg}$ $\mathrm{N}^{-1}$ at the end of the 80s to values between 0.4 and 0.7 for the water layers below 200 and $50 \mathrm{~m}$, respectively.
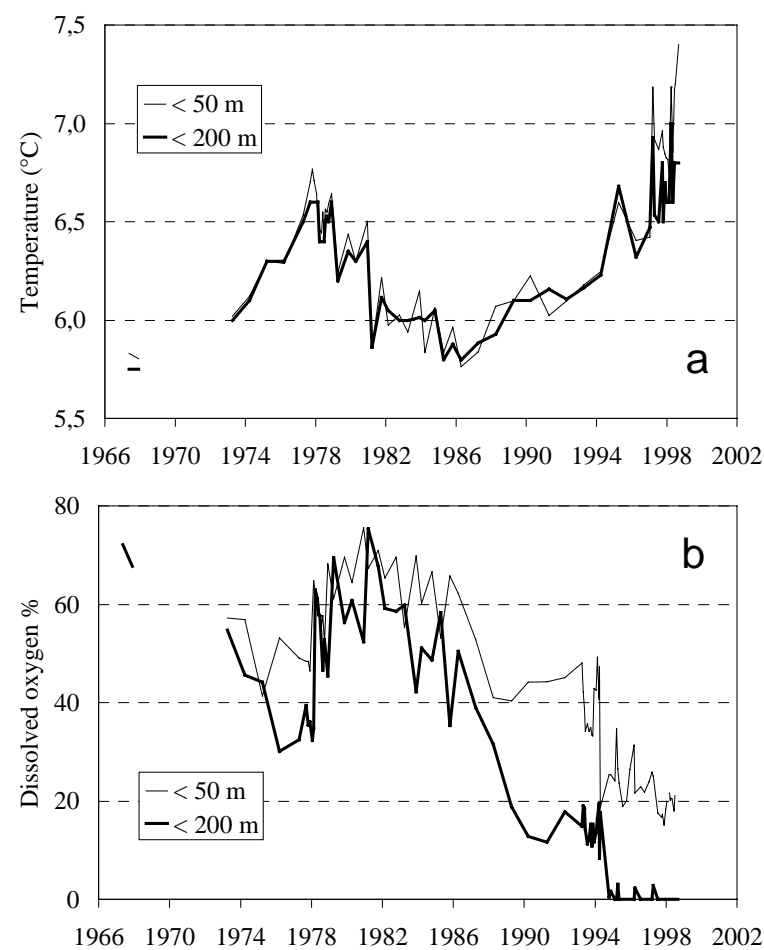

Fig. 3. Mean temperature (a) and oxygen saturation (b) in the water layers below 50 and $200 \mathrm{~m}$.

This decrease is mostly due to the reduction of nitrate, favoured by the poor oxygenation of the hypolimnion. The progressive worsening of the water quality is well also illustrated by the trend of reactive phosphorus (Fig. 4b), which has accelerated notably since 1984-86, reaching values close to 150 and $75 \mu \mathrm{g} \mathrm{P}^{-1}$ in the water layers below 200 and $50 \mathrm{~m}$. The mean values over the whole lake column were 56 and $66 \mu \mathrm{g} \mathrm{P}^{-1}$ respectively for reactive and total phosphorus in spring 1998.

Reactive silica concentrations (Fig. 4c) do not show such evident variations as those of TN and RP; values have been quite stable since the end of the eighties, while values were slightly higher, though with marked variations, in the seventies.
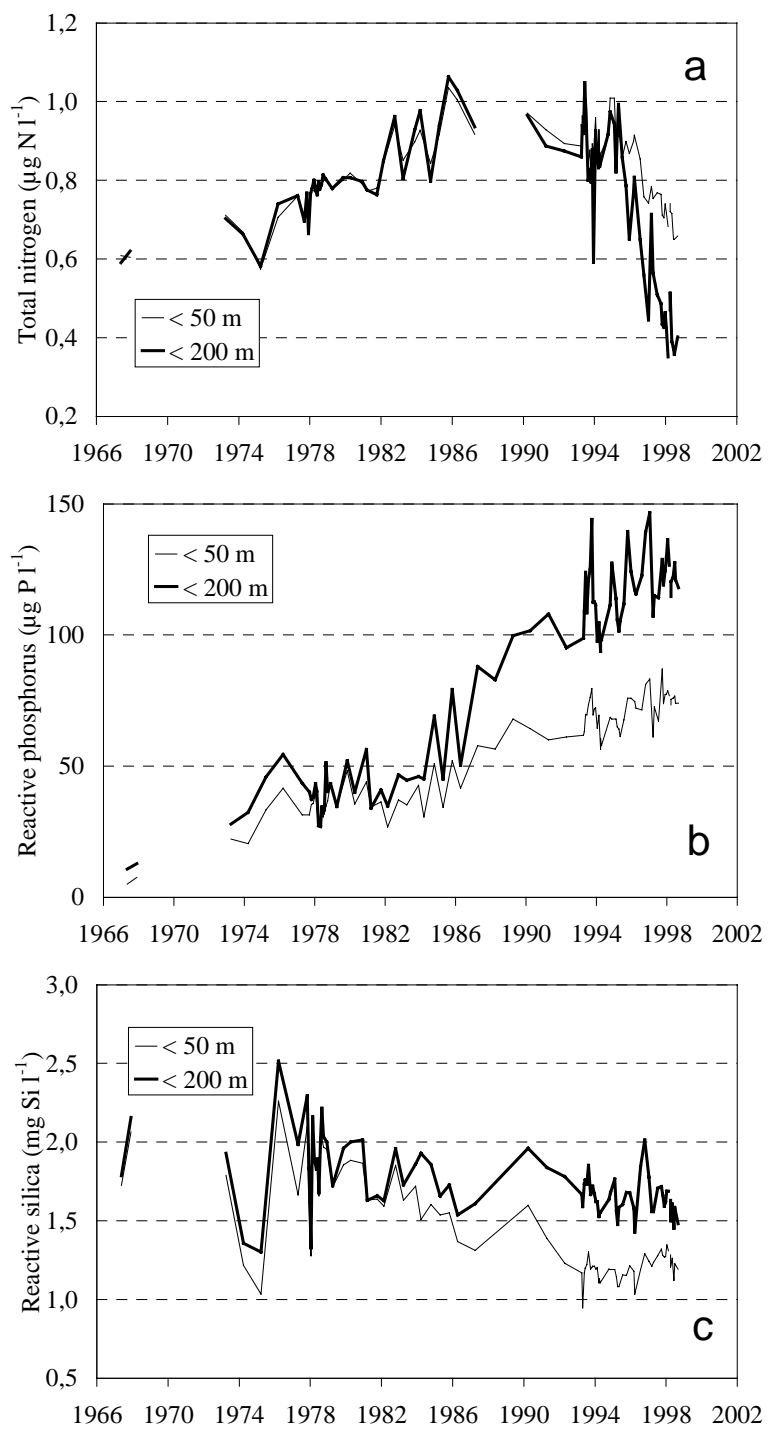

Fig. 4. Mean concentrations of total nitrogen (a), reactive phosphorus (b) and reactive silica (c).

\subsection{Chemical loads}

Taking into account the differences in the hydrology of the two years, and the different number of sampled tributaries, the chemical loads for 1995-96 and 1996-97 were considered and elaborated separately, as shown in tables 3 and 4 . Total inputs of the three variables considered were $20-25 \%$ higher in the second study year, due to the higher amount of precipitation. Considering the two experimental periods jointly, the total inputs can be estimated as around $3100 \mathrm{t} \mathrm{y}^{-1}$ for nitrogen, $90 \mathrm{t} \mathrm{y}^{-1}$ for phosphorus and $4700 \mathrm{t} \mathrm{y}^{-1}$ for reactive silica.

For the first study period (1995-96) loads were calculated using either all the measured concentrations, referring to $1605 \mathrm{~km}^{2}$ of the watershed area, or using only the data for the Oglio and the Borlezza (representing the contribution from $1570 \mathrm{~km}^{2}$ ) (Tab. 3). The comparison shows that the differences between the results using the 
Tab. 3. Mass balances for nitrogen, phosphorus and reactive silica from June 95 to May 96. The values in brackets are obtained from the concentrations of rivers Oglio inlet and Borlezza only (see text). Lake surface: input from atmospheric deposition on lake surface.

\begin{tabular}{lcccc}
\hline & $\mathrm{km}^{2}$ & $\begin{array}{c}\mathrm{TN} \\
\left(\mathrm{t} \mathrm{y}^{-1}\right)\end{array}$ & $\begin{array}{c}\mathrm{TP} \\
\left(\mathrm{t} \mathrm{y}^{-1}\right)\end{array}$ & $\begin{array}{c}\text { Reactive Si } \\
\left(\mathrm{t} \mathrm{y}^{-1}\right)\end{array}$ \\
\hline Rivers & $1605(1569.9)$ & $2400(2300)$ & $70(64)$ & $3800(3600)$ \\
Not sampled areas & $176(210.1)$ & $260(310)$ & $11(12)$ & $410(510)$ \\
Total watershed input & $1781(1781)$ & $2700(2600)$ & $81(76)$ & $4200(4100)$ \\
Lake surface & 61 & 60 & 0 & 0 \\
Total input & 1842 & 2800 & 81 & 4200 \\
Output & & 1500 & 23 & 600 \\
Input-Output & & 1300 & 58 & 3600 \\
In-lake retention $(\%)$ & & 46 & 72 & 86 \\
\hline
\end{tabular}

two methods are below $6 \%$ for TP and $4 \%$ for $\mathrm{TN}$ and $\mathrm{RSi}$. These variations are lower than the errors associated with the estimation of the chemical loads, which may be evaluated between 20 and $30 \%$. Comparing inputs and outputs evaluated for the two periods (Tabb $3,4)$, the lake retention percentage increases from nitrogen $(46-47 \%)$ to phosphorus $(72-75 \%)$ to silica $(86-85 \%)$. The higher in-lake retention for TP and RSi may be related to the higher percent uptake by phytoplankton, and to the subsequent sinking with the dead biomass.

Tab. 4. Mass balances for nitrogen, phosphorus and reactive silica from June 96 to May 97 . The values are given with two significant digits. Lake surface: input from atmospheric deposition on lake surface.

\begin{tabular}{lcccc}
\hline & $\mathrm{km}^{2}$ & $\begin{array}{c}\mathrm{TN} \\
\left(\mathrm{t} \mathrm{y}^{-1}\right)\end{array}$ & $\begin{array}{c}\mathrm{TP} \\
\left(\mathrm{t} \mathrm{y}^{-1}\right)\end{array}$ & $\begin{array}{c}\text { Reactive Si } \\
\left(\mathrm{t} \mathrm{y}^{-1}\right)\end{array}$ \\
\hline Rivers & 1569.9 & 2900 & 78 & 4600 \\
Not sampled areas & 211.1 & 400 & 19 & 620 \\
Total watershed input & 1781 & 3300 & 97 & 5200 \\
Lake surface & 61 & 70 & 0 & 0 \\
Total input & 1842 & 3400 & 97 & 5200 \\
Output & & 1800 & 24 & 820 \\
Input-Output & & 1600 & 54 & 4400 \\
In-lake retention $(\%)$ & & 47 & 75 & 85 \\
\hline
\end{tabular}

\section{DISCUSSION}

Because of the importance of phosphorus as the limiting factor for algal productivity, particular attention was paid to TP load assessment. To define the overall amount of TP entering the lake, loads calculated from experimental data on the main lake tributaries were integrated by theoretical estimates, carried out according to Marchetti (1995) on non-sampled areas. Criteria and coefficients were verified by comparing results of indirect estimates for areas drained by sampled tributaries $\left(82 \mathrm{t} \mathrm{P} \mathrm{y}^{-1}\right)$ with those deriving from experimental data (81 and $97 \mathrm{t} \mathrm{P} \mathrm{y}^{-1}$ for the two study periods, respectively). The good agreement between them made it possible to follow the criteria adopted by Marchetti (1995) for calculating the $\mathrm{P}$ loads from shoreline areas and those reaching the lake in the past, as well as to evaluate the relative importance of point and non-point sources. This was calculated on the basis of the ratio between point and non-point loads and total loads resulting from theoretical estimates. The values obtained were multiplied by the total experimental load.

To investigate the relationships between $\mathrm{P}$ loads and the trophic level of the lake, estimates were made for the past and for the situation which will probably emerge from the implementation of the measures envisaged by the Regional Water Recovery Plan (Regione Lombardia 1985). The final estimates are reported in table 5. According to the estimates, the load has dropped, in the last few years, from 200 to $93 \mathrm{t} \mathrm{P} \mathrm{y}^{-1}$. A further issue is that of the increasing importance of non-point sources, which rose from $25 \%$ to $53 \%$. This increase is clearly related to the decrease of point source loads due to the gradual connection of waste water to collectors and sewage treatment plants discharging either into the lake (after specific treatment steps for phosphorus removal leading to mean concentrations around $0.35 \mathrm{mg} \mathrm{P}$ $\mathrm{l}^{-1}$ ) or just outside the lake basin, into the outlet. Only a modest further reduction in $\mathrm{P}$ load can be expected once all the civil and industrial waste water is connected to the treatment plants, with an estimated decrease in the total load from the present $93 \mathrm{t} \mathrm{P} \mathrm{y}^{-1}$ to $85 \mathrm{t} \mathrm{P} \mathrm{y}^{-1}$.

Tab. 5. Calculated $\mathrm{P}$ loads $\left(\mathrm{P} \mathrm{y}^{-1}\right)$ for point and non-point sources in the present situation, before the construction of the sewage treatment plants and in the likely future when the planned recovery interventions will be completely realized.

\begin{tabular}{lccc}
\hline & Watershed & Shoreline & Total \\
\hline Present & & & \\
Point & 37 & 7 & 44 \\
Diffuse & 45 & 4 & 49 \\
Total & 82 & 11 & 93 \\
Past & & & \\
Point & 112 & 49 & 151 \\
Diffuse & 45 & 4 & 49 \\
Total & 147 & 53 & 200 \\
Future & & & \\
Point & 33 & 3 & 36 \\
Diffuse & 45 & 4 & 49 \\
Total & 78 & 7 & 85 \\
\hline
\end{tabular}

To investigate the relationships between the external phosphorus load and the trophic state of the lake, the 
theoretical average phosphorus concentration in the lake waters was calculated according to Vollenweider (1976) and OECD (1982). The first statistical approach relates the phosphorus loading, expressed as grams of $\mathrm{P}$ per square meter of lake surface per year, to the ratio between mean depth $(\mathrm{m})$ and theoretical water renewal time (year). The plots of the evaluated loads for the three periods (1986, 1995-97 and on completion of the planned recovery plants) versus the morphometric and hydraulic variables (Fig. 5) clearly show that the present of high trophic level of the lake is fully explained by the $\mathrm{P}$ loads, and that even when the recovery plants are completed the $\mathrm{P}$ load will be too high to keep the lake at an acceptable mesotrophic level.

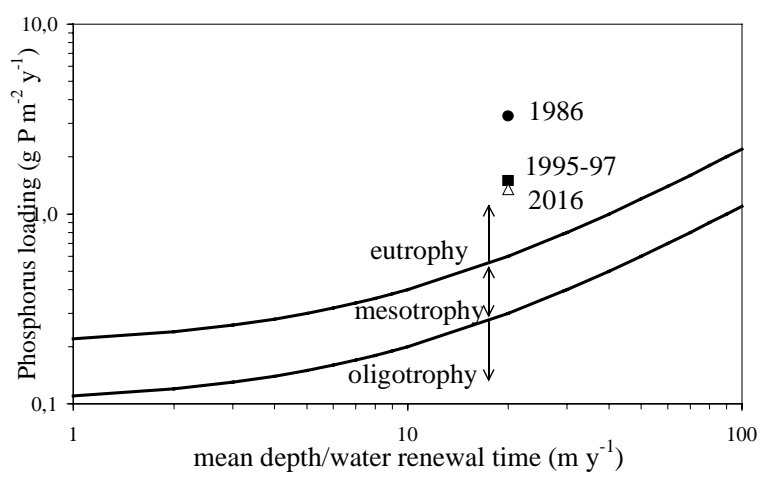

Fig. 5. Position of Lake Iseo P load at three stages of the waste water treatment following the approach by Vollenweider (1976). approach is probabilistic, and can be applied to a specific lake only if (a) the morphometric and hydrological characteristics of the lake, and the values of the chemical and biological variables, fall within the range of variation of the OECD lakes and (b) if the requisites of the models used in the OECD approach are fulfilled, i.e. steady state conditions, no change in concentration in the water column and no internal loading.

As is shown in table 6, the morphometric, hydrologic and chemical characteristics of Lake Iseo do fall within the range of the OECD lakes. The second condition, however, is not entirely satisfied, as there is in the lake no complete homogeneity of TP concentration on the water column, due to the lack of complete overturn. Bearing this limitation in mind, the result of the plot of the three load patterns $(1986,1996,2016)$ is shown in figure 6 . Average phosphorus concentration in the inflowing waters was derived from calculated loads in the three chosen options and annual inflow data supplied by Consorzio dell'Oglio; hydraulic retention time was estimated as 4.2 years, on the basis of the 1951-1996 hydrological data.

The graph uses a different range of TP concentrations to define the areas of higher probability of oligotrophy, mesotrophy and eutrophy. The two threshold concentrations used in the original OECD approach are 8 and $25 \mu \mathrm{g} \mathrm{P}{ }^{-1}$, respectively; the higher value was lowered to $15 \mu \mathrm{g} \mathrm{P}^{-1}$, taking into account the characteristics of the deep southern Alpine lakes, which begin to show clear signs of eutrophication when TP concen-

Tab. 6. Morphometric and hydrological parameters, loads and concentrations of nitrogen and phosphorus, in-lake concentrations of chlorophyll- $a$ (0-10 m means) compared with the range and geometric means of the same variables in the OECD lakes.

\begin{tabular}{|c|c|c|c|c|c|c|c|}
\hline & \multirow[t]{2}{*}{ Symbol } & \multirow[t]{2}{*}{ Unit } & \multirow[t]{2}{*}{ L. Iseo } & \multicolumn{4}{|c|}{ OECD lakes } \\
\hline & & & & Min. & Geometric mean & Max. & Studied lakes \\
\hline Lake area & Ao & $\mathrm{km}^{2}$ & 61 & 0.025 & 6.6 & 58000 & 126 \\
\hline Mean depth & $z$ & $\mathrm{~m}$ & 123 & 1.7 & 14.3 & 313 & 126 \\
\hline Water residence time & $\tau_{\omega}$ & years & 4.2 & 0.016 & 1.2 & 700 & 112 \\
\hline Loading of TP & $L(P)$ & $\mathrm{g} \mathrm{m}^{-2} \mathrm{y}^{-1}$ & 1.31 & 0.017 & 1.2 & 80 & 102 \\
\hline Outflow of TP & $O(P)$ & $\mathrm{g} \mathrm{m}^{-2} \mathrm{y}^{-1}$ & 0.38 & 0.040 & 0.74 & 80 & 61 \\
\hline Annual mean inflow of TP & {$[\mathrm{P}]_{i}$} & $\mathrm{mg} \mathrm{m}^{-3}$ & 50 & 4.7 & 112 & 1425 & 92 \\
\hline Annual mean in-lake concentration of TP & {$[\mathrm{P}]_{\lambda}$} & $\mathrm{mg} \mathrm{m}^{-3}$ & 64 & 3.0 & 47 & 750 & 115 \\
\hline Loading of TN & $L(N)$ & $\mathrm{g} \mathrm{m}^{-2} \mathrm{y}^{-1}$ & 51 & 0.81 & 28 & 1710 & 56 \\
\hline Outflow of TN & $O(N)$ & $\mathrm{g} \mathrm{m}^{-2} \mathrm{y}^{-1}$ & 27 & 0.20 & 20 & 1710 & 48 \\
\hline Annual mean inflow of TN & {$[\mathrm{N}]_{i}$} & $\mathrm{mg} \mathrm{m}^{-3}$ & 1920 & - & - & - & - \\
\hline Annual mean in-lake concentration of TN & {$[\mathrm{N}]_{\lambda}$} & $\mathrm{mg} \mathrm{m}^{-3}$ & 810 & 263 & 1244 & 6095 & 58 \\
\hline Mean annual chlorophyll- $a$ & {$\left[\mathrm{Chl}_{a}\right]$} & $\mathrm{mg} \mathrm{m}^{-3}$ & 5 & 0.3 & 8.4 & 89 & 96 \\
\hline Annual peak of chlorophyll & {$\left[\max \mathrm{Chl}_{a}\right]$} & $\mathrm{mg} \mathrm{m}^{-3}$ & 18 & 2.0 & 22.8 & 275 & 61 \\
\hline TP residence time & $\tau_{p}$ & years & 5.4 & 0.006 & 0.53 & 24.5 & 97 \\
\hline
\end{tabular}

The second statistical approach (OECD 1982), which is a development of the first, uses the theoretical water renewal time and the mean TP concentrations in inflowing waters to evaluate the trophic level of the lake, by calculating the in-lake TP concentration and chlorophyll a concentration. The nature of the OECD trations exceed $10 \mu \mathrm{g} \mathrm{P}{ }^{-1}$ (Ravera \& Vollenweider 1968; Ambrosetti et al. 1983b, 1992; Salmaso et al. 1997).

The plot of the loads corresponding to the three periods clearly shows that the lake before 1986 was in the area of high probability of eutrophy, which is in agree- 
ment with the trophic evolution observed in Lake Iseo from the first study in 1965 (Bonomi \& Gerletti 1967, Garibaldi et al. 1997). On the other hand, the in-lake TP concentrations which should be currently expected on the basis of the statistical relationship (about $35 \mu \mathrm{g} \mathrm{P} \mathrm{l}^{-1}$ ) is significantly lower than the present $\mathrm{P}$ concentrations (60-65 $\mu \mathrm{g} \mathrm{P}^{-1}$ ). This may be explained by (a) an underestimation of the present TP load, (b) the presence of a significant internal P load or (c) a discrepancy between some characteristics of the lake and the requirements of the model. Point (a) may reasonably be rejected on the basis of the detailed sampling of the tributaries performed in the first year of this study. On the other hand, a detailed study on soil use and productive activities in the watershed (Garibaldi et al. 1998) did not indicate the presence of significant potential $\mathrm{P}$ sources in the areas not drained by the tributaries. The importance of the internal $\mathrm{P}$ load (point $\mathrm{b}$ ) is certainly not substantial in a lake with a maximum depth of $250 \mathrm{~m}$ and little tendency to present full circulation. Things may have been changing since 1994, when anoxia appeared in the bottom layer (Garibaldi et al. 1995). However, this does not seem to be enough to determine the observed differences in $\mathrm{P}$ concentrations. As to the third point, the most important discrepancy of Lake Iseo with the OECD requirements is the lack of overturn, which produces, along with phytoplankton uptake and sedimentation, a gradient of TP concentration over the water column, so that the TP concentration in the outlet is significantly lower than the in-lake mean values.

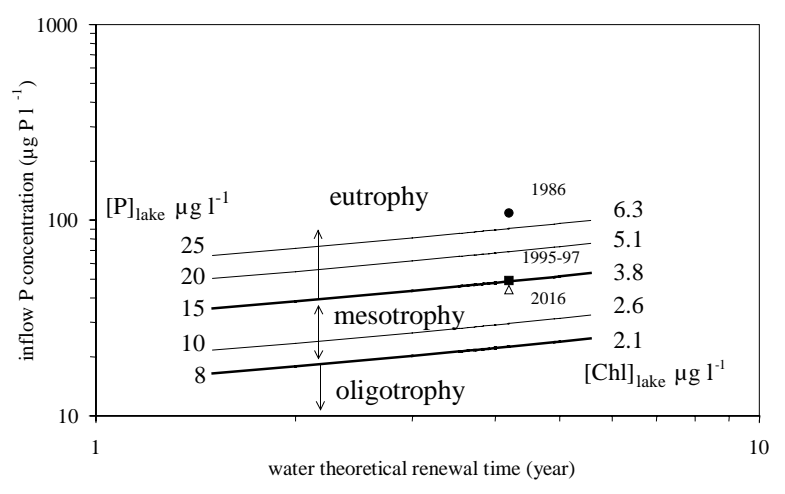

Fig. 6. OECD (1982) synthesis diagram and position of Lake Iseo P load in three stages of the wastewater treatment.

The complete overturn, which in the deep southern Alpine lakes would normally be in March-April, has become rare in recent years, with the last complete overturn occurring in Lake Iseo, as well as in the other deep subalpine lakes, in the early $80 \mathrm{~s}$. The variations of dissolved oxygen and reactive phosphorus in the deeper water layer well illustrate the lack of overturn in recent years (Figg 3, 4).

As is shown in figure 6, according to the OECD model, the estimated water phosphorus concentrations should be much lower than the measured ones, ranging, in the present situation, between 16 and $18 \mu \mathrm{g} \mathrm{P} \mathrm{l}^{-1}$ and, in the past, between 31 and $36 \mu \mathrm{g} \mathrm{P} \mathrm{l}^{-1}$. Completion of the recovery interventions, on the other hand, would lead to a further reduction of about $10 \mathrm{t} \mathrm{P} \mathrm{y}^{-1}$, resulting, according to OECD, in a decrease of about $2 \mu \mathrm{g} \mathrm{P} \mathrm{l}^{-1}$ in lake phosphorus concentration. So, even taking into account the length of time required for the lake to show recovery symptoms after phosphorus load reduction, often much longer than the theoretical water renewal time, the situation of the lake does not seem consistent with the load estimates. In fact, according to the OECD regression, the phosphorus load reaching the lake in the past would have to have been much lower to justify the present in-lake concentrations. Actually, while at a first glance the OECD model would seem to fit the case of Lake Iseo, it is worth observing that the situation has been significantly modified by the absence of complete overturn periods. One of the prime conditions for the application of OECD models, i.e. the complete mixing of the lake waters, is therefore lacking, and the sourcereceptor relationships seem to follow a different trend. It is more and more difficult to make an estimate of expected phosphorus in the lake, and a gradual enhancement of the trophic level is also the result of the accumulation of nutrients deriving from the long lasting stagnation of the water.

\section{CONCLUSIONS}

Since the first regular sampling performed in 1973, the trophic state of Lake Iseo has continued to increase, as is shown by the growing TP concentrations, the anoxia of the water below $200 \mathrm{~m}$ and the frequent presence of toxic algae in the phytoplankton (Garibaldi et al. 1995 ; 1997). There appears to be no remission of this process, notwithstanding the significant reduction in the $\mathrm{P}$ load which the construction of treatment plants has produced over the last 10 years. One cause of the deterioration of the lake is the lack of complete overturns. This is due partly to climatic factors (mild winters), and partly to the accumulation of nutrient salts in the hypolimnion, which has caused a general increase in salinity and favoured the stagnation of the water observed in recent years. In its turn, the accumulation of salts depends mainly on the precipitation of calcium carbonate, which is a direct effect of high productivity in water rich in calcium and bicarbonate, as is the case with Lake Iseo. The reduced tendency to total mixing of the whole water column is likely to result in a higher sensitivity to the phosphorus load of the lakes, i.e. a higher trophic state of the lake with the same P load.

The absence of complete overturn is probably the chief reason why the OECD approach produces misleading results. There is a clear necessity to carry out further research specifically aimed at defining an acceptable load, taking into account the lack of regular periods of water overturn. However, the results we have are sufficient for us to say that the present load, while 
consistent with the Regional Water Recovery Plan strategy, is still too high not only to allow the recovery of the lake but also to stop its growing eutrophication. Unfortunately, as we have said above, most of the present phosphorus load derives from non-point sources and is thus not likely to be reduced, while all the technological solutions for reducing point source loads have already been implemented.

Interventions aimed at further reducing the point source load could be planned, but would involve high costs and much uncertainty about their cost effectiveness. Phosphorus removal by chemical co-precipitation, for instance, could be adopted even in small treatment plants. The level of storm water overflow could also be reduced, and storm water collected during rain events could be precipitated chemically before being discharged into the lake. However, it is improbable that these options would lead to more than marginal benefits in terms of mass balance and allow more than a small decrease in the overall phosphorus load. On the other hand, more detailed limnological studies should also consider the processes leading to $\mathrm{P}$ elimination from the water, e.g. co-precipitation with calcium carbonate and with phytoplankton biomass. In this last process a major role is played by the sedimentation of diatoms, which are of great importance in Lake Iseo (Garibaldi et al. $1995,1997)$, and by the silica budget, which shows a marked Si retention in the lake.

\section{ACKNOWLEDGMENTS}

We wish to thank Prof. Oscar Ravera of the C.N.R. Istituto Italiano di Idrobiologia for his valuable suggestions and critical reading of the paper. The Water Authority Consorzio dell'Oglio provided inflow and outflow water volumes.

\section{REFERENCES}

Ambrosetti, W. \& L. Barbanti. 1992. Physical Limnology in Italy: a historical review. In: Guilizzoni, P., G. Tartari \& G. Giussani (Eds), Limnology in Italy. Mem. Ist. ital. Idrobiol., 50: 37-59.

Ambrosetti, W., L. Barbanti \& A. Rolla. 1983a. Considerazioni sulla dinamica del mescolamento nei laghi profondi sudalpini. Atti $5^{\circ}$ Congr. A.I.O.L., Stresa, 19-22 Maggio 1982: 101-112.

Ambrosetti, W., L. Barbanti, R. Mosello \& A. Pugnetti. 1992. Limnological studies on the deep southern Alpine lakes Maggiore, Lugano, Como, Iseo and Garda. In: Guilizzoni, P., G. Tartari \& G. Giussani (Eds), Limnology in Italy. Mem. Ist. ital. Idrobiol., 50: 117-146.

Ambrosetti, W., L. Barbanti, R. Mosello, A. Rolla \& D. Ruggiu. 1983b. Mescolamento, caratteristiche chimiche, fitoplancton e situazione trofica nei laghi profondi sudalpini. C.N.R.-P.F. Promozione della Qualità dell'Ambiente, $\mathrm{AQ} / 2 / 20: 11-51$.

A.P.H.A., A.W.W.A., W.P.C.F. 1985. Standard Methods for the examination of water and wastewater. Am. Publ. Health Ass., Washington: 1268 pp.

Barbanti, L. \& W. Ambrosetti. 1985. The behaviour of hypolimnetic oxygen in Lago Maggiore in recent years. Mem. Ist. ital. Idrobiol., 43: 33-54.
Barbanti, L. \& W. Ambrosetti. 1989. The physical limnology of Lago Maggiore: a review. Mem. Ist. ital. Idrobiol., 46: 41-68.

Bonomi, G. 1968. Le acque lacustri dell'Italia settentrionale. La situazione attuale dei grandi laghi prealpini. In: Il problema delle acque in Italia, parte seconda: le acque dolci superficiali. FAST, Milano, 5-7 luglio 1967: 23-105.

Bonomi, G. \& M. Gerletti. 1967. Il Lago d'Iseo: primo quadro limnologico generale (termica, chimica, plancton e benton profondo). Mem. Ist. ital. Idrobiol., 22: 149-175.

Bonomi, G., A. Calderoni \& R. Mosello. 1979. Some remarks on the recent evolution of the deep Italian subalpine lakes. Symp. Biol. Hung., 19: 87-111.

Consorzio dell'Oglio. 1952. La regolazione del Lago d'Iseo nel primo quindicennio di esercizio (1933-1947). Parte I. Osservazioni e dati idrologici. Morcelliana, Brescia.

Consorzio dell'Oglio. 1984. La regolazione del Lago d'Iseo nel ventitreennio 1957-1979. Poligrafica Bresciana, Brescia: $225 \mathrm{pp}$.

Consorzio dell'Oglio. 1986. La regolazione del Lago d'Iseo nel sessennio 1980-1985. Poligrafica Bresciana, Brescia: $95 \mathrm{pp}$.

Consorzio dell'Oglio. 1993. La regolazione del Lago d'Iseo negli anni dal 1986-1992. Apollonio \& C., Brescia: 83 pp.

Cordella, P. 1973. Notizie generali e nuovi dati morfometrici per uno studio ambientale sul Lago d'Iseo. Riv. Idrobiol., 12: $97-105$.

Cordella, P. \& E.M. Paganelli-Cappelletti. 1975. Clorofilla- $a$ nella zona centrale del Lago d'Iseo: relazioni tra la concentrazione superficiale e la concentrazione media nello strato eufotico. Riv. Idrobiol., 14: 273-281.

Cordella, P., A. Paganelli \& R. Trevisan. 1976. Ricerche idrobiologiche sul Lago d'Iseo. I. Lineamenti della ricerca, condizioni chimico-fisiche, nutrienti algali. Riv. Idrobiol., 15: 205-236.

Cordella, P., A. Paganelli, E.M. Paganelli-Cappelletti \& R. Trevisan. 1977. Alcune considerazioni sul trofismo delle acque del Lago d'Iseo nell'ultimo decennio. Atti VII Simp. Naz. Conservazione della natura. Bari, 20-23 aprile 1977: 213-224.

Cordella P., A. Paganelli, E.M. Paganelli-Cappelletti, R. Trevisan. 1982. Primary production and clorophyll- $a$ in the central zone of Lake Iseo (northern Italy). Mem. Ist. ital. Idrobiol., 40: 99-112.

Cordella, P., R. Trevisan, A. Miola, E.M. Paganelli-Cappelletti \& A. Paganelli. 1979. Carico di fosforo ed eutrofizzazione del Lago d'Iseo. Atti VIII Simp. Naz. Conservazione della natura. Bari, 26-28 aprile 1979: 403-411.

Cordella, P., A. Miola, R. Trevisan, E.M. Paganelli-Cappelletti \& A. Paganelli. 1980. Concentrazioni di fosforo e azoto inorganico in tre laghi del Nord Italia. Atti I Congr. Naz. S. It. E., Salsomaggiore Terme, 21-24 ottobre 1980: 117-121.

Garibaldi, L., M.C. Brizzio, V. Mezzanotte, A. Varallo \& R. Mosello. 1995. The continuing evolution of Lago Iseo (N. Italy): the appearance of anoxia. Mem. Ist. ital. Idrobiol., 53: 191-212.

Garibaldi, L., M.C. Brizzio, V. Mezzanotte, A. Varallo \& R. Mosello. 1997. Evoluzione idrochimica e trofica del Lago d'Iseo. Documenta Ist. ital. Idrobiol., 61: 135-151.

Garibaldi, L., V. Mezzanotte, M.C. Brizzio, A. Varallo \& R. Mosello. 1998. Apporti di fosforo al Sebino. Confronto tra misure sperimentali e teoriche. Acqua e Aria, 9: 105-110.

Marchetti, G. 1995. The Eutrophication of Lake Iseo (Italy): causes, evolution and restoration management. Thesis for E.A.E.M.E. Postgraduate Program 1994-95 in Environmental Management: $52 \mathrm{pp}$.

Mosello, R. 1983. Il livello trofico dei laghi profondi sudalpini sulla base delle loro concentrazioni di azoto, fosforo e ossigeno disciolto. Atti $5^{\circ}$ Congr. A.I.O.L., Stresa, 19-22 maggio 1982: 607-616. 
Mosello, R. 1993. Rapporto sull'attività della rete RIDEP nel quinquennio 1988-92. RIDEP n. 13. Documenta Ist. ital. Idrobiol., 44: $118 \mathrm{pp}$.

Mosello, R. \& A. Marchetto. 1995. Chemistry of atmospheric deposition in Italy: results from a five year study. Ambio, 25: 21-25.

Mosello, R. \& G. Giussani (Eds). 1997. Evoluzione recente della qualità selle acque dei laghi profondi sudalpini. Documenta Ist. ital. Idrobiol., 61: $230 \mathrm{pp}$.

O.E.C.D. 1982. Eutrophication of waters. Monitoring, assessment and control. O.E.C.D. Publication $\mathrm{N}^{\circ} 42077$, Paris: $154 \mathrm{pp}$.

Paganelli, A., P. Cordella \& R. Trevisan. 1975. Ricerche idrologiche sul Lago d'Iseo: materiali e metodi sul campo. Proc. Int. Seminar Lacustrine Environment. Methods of Study. Como, 28-30 novembre 1975: 197-202.

Paganelli, A., P. Cordella, R. Trevisan Pertile \& M.R. Ramon. 1976. Ricerche sul fitoplancton e la chimica delle acque del Lago d'Iseo. Giorn. Bot. Ital., 110: 458-460.

Paganelli, A., P. Cordella, R. Trevisan, E.M. Cappelletti \& F. Ascensi. 1979. Evoluzione delle condizioni trofiche del Lago d'Iseo nell'arco di un decennio (1967-1977).
In:C.N.R. Progetto Finalizzato Promozione della qualità dell'ambiente. Atti del convegno sull'eutrofizzazione in Italia. Roma 3-4 ottobre 1978: 281-302.

Ravera, O. \& R.A. Vollenweider. 1968. Oscillatoria rubescens D.C. as an indicator of Lago Maggiore eutrophication. Schweiz. Z. Hydrol., 30: 374-380.

Regione Lombardia. 1985. Piano regionale di risamento delle acque. Lombardia Risorse, Milano.

Salmaso, N., F. Decet \& R. Mosello. 1997. Chemical characteristics and trophic evolution of the deep subalpine Lake Garda (Northern Italy). Mem. Ist. ital. Idrobiol., 56: 15-24.

Trevisan, R., A. Paganelli, P. Cordella, E.M. Cappelletti \& F. Ascensi. 1979. Ricerche idrobiologiche sul Lago d'Iseo. III. Popolamenti fitoplanctonici. Riv. Idrobiol., 18: 271307.

Valderrama, J.C. 1981. The simultaneous analysis of total nitrogen and total phosphorus in natural waters. Mar. Chem., 10: 109-122.

Vollenweider, R.A. 1976. Advances in defining critical loading for phosphorus in lake eutrophication. Mem. Ist. ital. Idrobiol., 33: 53-83. 